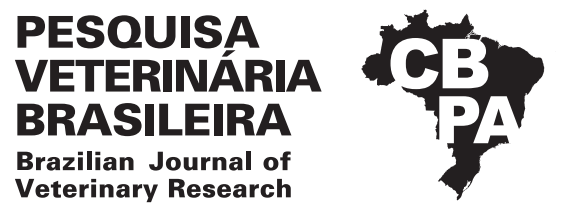

Pesq. Vet. Bras. 38(9):1849-1855, setembro 2018 DOI: 10.1590/1678-5150-PVB-5175

Original Article

Morfofisiologia/Morphophysiology

ISSN 0100-736X (Print)

ISSN 1678-5150 (Online)

\title{
Morphometry of pectoral muscle fiber and intestinal villi of Calidris pusilla during the wintering period in Brazil $^{1}$
}

\author{
Felipe Q. Chaves², Nailson A. Neri Júnior³, Roberta C. Rodrigues ${ }^{2,4}$, \\ Helder F.P. Araujo ${ }^{5}$ and Ricardo R. Guerra ${ }^{2,6 *}$
}

\begin{abstract}
Chaves F.Q., Neri Júnior N.A., Rodrigues R.C., Araujo H.F.P. \& Guerra R.R. 2018. Morphometry of pectoral muscle fiber and intestinal villi of Calidris pusilla during the wintering period in Brazil. Pesquisa Veterinária Brasileira 38(9):1849-1855. Laboratório de Histologia Animal, Centro de Ciências Agrárias, Universidade Federal da Paraíba, Cidade Universitária, Areia, PB 58397-000, Brasil. E-mail: rromaoguerra@gmail.com

Migration is an event observed in several animals, such as shorebirds moving between the northern and southern hemispheres, during breeding and wintering intervals. Morphophysiological adaptations are necessary to allow the maintenance of migratory cycles and, therefore, studies with this focus can help clarify biological aspects related to migration. We analyzed the morphology variation in pectoral muscles and intestinal mucosa of Calidris pusilla, during different phases of the wintering period on the coast of Brazil. Fragments of pectoral muscles and duodenal were collected, fixed and processed for histology according to standard procedure, from specimens captured in a locality on the Brazilian coast. Modifications were found in the measured parameters among the three phases of wintering, arrival in Brazil (October, mid-period), January and departure to the Northern Hemisphere May. The registered structural dynamism characterizes the growth of flight musculature and intestinal changes related to nutrition. Such changes occur temporarily due to the activities of preparation and migration between the northern and southern hemispheres.
\end{abstract}

INDEX TERMS: Morphometry, pectoral muscle fiber, intestinal villi, Calidris pusilla, wintering, Brazil, bird migration, Charadriiformes, histology, morphology.

RESUMO.- [Morfometria da fibra muscular peitoral e das vilosidades intestinais de Calidris pusilla durante o período de invernada no Brasil.] A migração é um evento observado em vários animais, como as aves limícolas que se deslocam entre os hemisférios norte e sul, durante os intervalos

\footnotetext{
${ }^{1}$ Received on December 18, 2017.

Accepted for publication on December 21, 2017.

${ }^{2}$ Programa de Pós-Graduação em Ciência Animal, Centro de Ciências Agrárias (CCA), Universidade Federal da Paraíba (UFPB), Cidade Universitária, Areia, PB 58397-000, Brazil. *Corresponding author: rromaoguerra@gmail.com

${ }^{3}$ Graduando de Medicina Veterinária, Centro de Ciências Agrárias (CCA), Universidade Federal da Paraíba (UFPB), Cidade Universitária, Areia, PB 58397-000.

${ }^{4}$ Faculdade Rebouças de Campina Grande, Avenida Min. José Américo de Almeida 477, Santo Antônio, Campina Grande, PB 58406-040, Brazil.

${ }^{5}$ Departamento de Ciências Biológicas (DCB), Centro de Ciências Agrárias (CCA), Universidade Federal da Paraíba (UFPB), Cidade Universitária, Areia, PB 58397-000.

${ }^{6}$ Laboratório de Histologia Animal, Departamento de Ciências Veterinárias (DCV), Centro de Ciências Agrárias (CCA), Universidade Federal da Paraíba (UFPB), Cidade Universitária, Areia, PB 58397-000.
}

de reprodução e invernada. Adaptações morfofisiológicas são necessárias para permitir a manutenção dos ciclos migratórios e, portanto, estudos com esse enfoque podem ajudar a esclarecer aspectos biológicos relacionados à migração. Analisamos a variação morfológica nos músculos peitorais e mucosa intestinal de Calidris pusilla, durante diferentes fases do período de invernada no litoral brasileiro. Fragmentos de músculos peitorais e duodenais foram coletados, fixados e processados para histologia de acordo com o procedimento padrão, a partir de espécimes capturados na localidade da costa brasileira. 0 dinamismo estrutural registrado caracteriza o crescimento da musculatura de vôo e as alterações intestinais relacionadas à nutrição. As mudanças nos parâmetros medidos entre as três fases do inverno, chegada ao Brasil (outubro, meio período), janeiro e saída para o Hemisfério Norte. Tais mudanças ocorrem temporariamente devido às atividades de preparação e migração entre os hemisférios norte e sul.

TERMOS DE INDEXAÇÃO: Morfometria, fibra muscular peitoral, vilosidade intestinal, Calidris pusilla, invernada, Brasil, migração, Charadriiformes, histologia, morfologia. 


\section{INTRODUCTION}

Migration is a biological behavior that has developed, independently, in several animal groups, in which populations perform cyclical and seasonal displacements, usually associated with food and reproductive factors that are necessary to the life cycle of these animals (Morrison 1984, Alerstam et al. 2003). The Calidris pusilla species (Linnaeus, 1957) of the Charadriiformes order and the Scolopacidae family (Phillips 1975 ) is one of the migratory wading birds that spend part of the year on the Brazilian coast. As phenotypic features, it has a black beak and black legs (Sick 1997). Specimens of C. pusilla arrive in Brazil between August and September and return to breeding sites in April and May (Larrazábal et al. 2002), and remain at several wintering sites in the Northeast region (Oliveira et al. 2016). In these areas, in addition to the exchange of feathers that is essential to the flight, these birds gain mass, which is reflected in the accumulation of sufficient energy for the continuity of the cycle (Rodrigues et al. 2009). The species has a capacity for long flights related to the long migratory routes that it performs (Fig.1) and, according to Azevedo-Júnior et al. (2002), analysis of the species flight capacity has led to the conclusion that $C$. pusilla can fly up to 3,545.77 kilometers. Due to the importance that displacement has to this bird, part of its anatomical characteristics is related to the flight, which is its main form of displacement (Landini et al. 2013).

A great phenotypic and metabolic flexibility occurs during long distance flights, determined by tissue turnover rates and provided by functional strategies of economy and physiological efficiency (Bauchinger \& McWilliams 2010). At first, the changes in body mass of the birds were attributed to differences only in body fat content (Connell et al. 1960, Odum et al. 1964, Blem 1980). However, other studies have shown that, like fat content, lean mass also changes during the migratory period (Lindstrom \& Piersma 1993, Jehl 1997, Karasov \& Pinshow 1998, Battley et al. 2000), suggesting a change in the size of organs and muscle groups. The muscles that play an essential role in the movement of the wings are the pectoral and supracoracoid muscle (Biewener 2011) and therefore correspond to strategic muscles to verify the influence of any migration-related variations.

On the northern and northeastern coast of Brazil, during the wintering period, the variation in body mass of $C$. pusilla individuals is characterized by the lower values recorded at the arrival period, after displacement towards the Southern Hemisphere, and higher values close to the moment of migration to the Northern Hemisphere, when the destination corresponds to the breeding sites (Rodrigues et al. 2016). Pires (2008) found that in commercial birds the mucosa of the

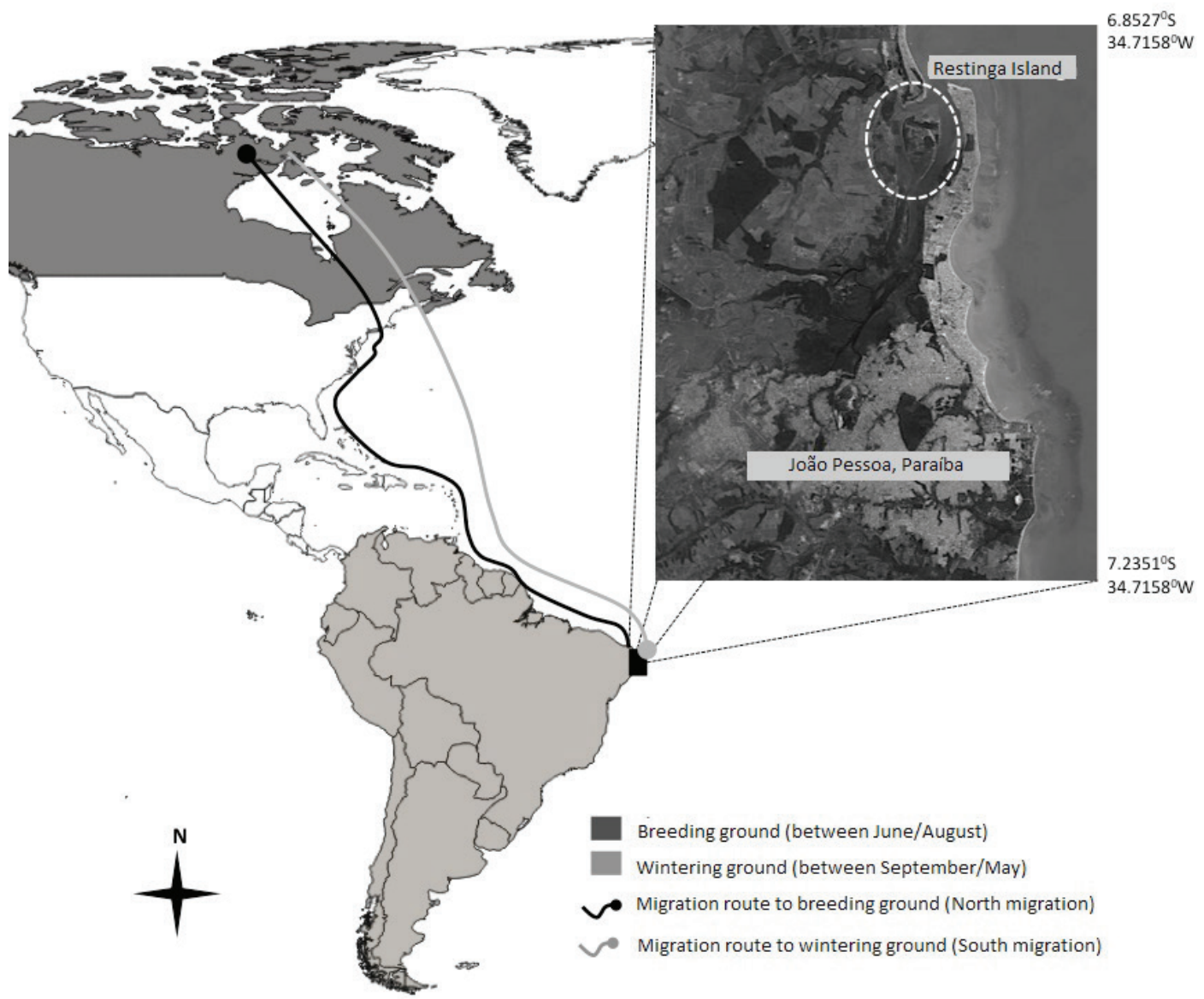

Fig.1. Map of the migration routes of Calidris pusilla in the Americas with their respective periods and satellite photo of the study area on Restinga Island/PB, Brazil. 
gastrointestinal tract has the highest rate of renewal among all the tissues of the body, and are susceptible to changes in the diet. Therefore, changes in the gastrointestinal mucosa of C. pusilla may be related to the different physiological aspects that allow the variation in mass accumulation during different stages of the migratory cycle.

Morphometry techniques are quite useful in evolutionary biology to aid in the interpretation and comparison of quantitative character variation patterns (Cavalcanti \& Lopes 1990), allowing the study of variation and covariation of distance measures when combined with statistical resources (Cadrin 2000, Moraes 2003). There are no studies that evaluate the pectoral muscle and the intestine of $C$. pusilla morphometrically, and therefore, studies with this focus can be a suitable tool to aid in the understanding of the capacity of the long distance migration performed by relatively small animals, such as the species target of this study.

In addition, there is a record of the reduction in the populations of $C$. pusilla on a global level (Andres et al. 2012) and, consequently, the knowledge about its biological aspects related to migration is extremely important to assist in population monitoring and in the search for causes of this reduction so that effective conservation measures can be taken. Since there are no papers focused on the aspects of the histological alterations of waders, this study may help in the biological understanding of the migration of these birds and, therefore, may help to understand aspects related to the physiology of the migration of other endangered migratory species.

Thus, in this study we intend to verify if there is alteration in the histomorphometric parameters of the muscle fibers in the pectoral muscle and intestinal structures of $C$. pusilla, between different phases, during the wintering period. As the beginning of this period is characterized by the arrival of a long flight from the Northern Hemisphere to the South, for about only 6 days (Brown \& Jordan 2014), and the end is marked by increased body mass and preparation for the return to the north, it is expected that: 1) the muscle fibers are smaller on arrival in Brazil due to migratory wear, and larger fibers are recorded at the end of wintering; and 2) changes in intestinal histological parameters related to greater nutritional efficiency are more frequent during the arrival and departure periods, since these periods are temporally related to the mass accumulation resulting from the supply a few days before arrival in South America, as well as the increase in mass during preparation for migration north.

\section{MATERIALS AND METHODS}

The methodological protocols of this research were approved by the Ethics Commission for Animal Use at the Federal University of Paraíba and registered under protocol number 172/2015, and the authorization to carry out the study was granted by the System of Biodiversity Authorization and Information (SISBio), filed under the protocols 47023-1 and 47023-2.

Area of study and capture of birds. The collections were carried out in Restinga Island, Cabedelo, state of Paraíba (6 $6^{\circ} 59^{\prime} 6^{\prime \prime} \mathrm{S}$ and $34^{\circ} 51^{\prime} 52^{\prime \prime} \mathrm{W}$ ), a fluvial-marine island located near the mouth of the Paraíba River (Fig.1). The collections were carried out in the months of May and October of 2015 and January of 2016. Each month represents a phase of the wintering period of these birds: October corresponds to the time of arrival in Brazil, after the reproductive period and end of the south migration; January is mid-wintering period; and May, the period of preparation and beginning of the northern migration, when the birds move to the breeding sites. The capture of the birds was performed with mist nets $(12 \times 2.5 \mathrm{~m})$ with $36 \mathrm{~mm}$ mesh, installed in places of frequent use of these birds.

Collection of tissue samples. Forty-three individuals of the species C. pusilla were euthanized through cervical displacement: 15 in October, 15 in January and 13 in May, representing the phases of the wintering period related to south migration (arrival), mid-wintering period, and northern migration (departure). Samples of $0.5 \mathrm{~cm}^{3}$ from the pectoral muscle and $1 \mathrm{~cm}$ segments from the duodenum were collected for histological analysis, with fixation in $10 \%$ formaldehyde solution.

Sample processing and morphometry of pectoral muscle fiber and intestinal villi and crypts. The fragments of the pectoral muscles and the duodenum were dehydrated in increasing solutions of alcohol (from $70 \%$ up to 100\%) and diaphonized in Xylol, and then submitted to baths and inclusion in paraffin. Microtoming was performed by obtaining cuts of $5 \mu \mathrm{m}$ of thickness. The samples were then submitted to routine histological staining (hematoxylin and eosin, HE and periodic acid Schiff, PAS) (Junqueira \& Carneiro 2008). The slides were analyzed under an Olympus BX-60 microscope and the photomicrographs were performed with a ZeissAxioCam coupled camera with the use of the Ks-400 digital imaging capture program.

To determine the thickness of the pectoral muscle fibers from the histological images of the pectoral muscle of each animal under the microscope, 5 different fields were digitalized with a 40x objective each unit, and in each field, 8 measurements were performed (Fig.2B) randomly, totaling 40 measurements per animal, or 520 measurements per period (south migration, mid-period, north migration).

To determine villus height, as well as depth of crypt, at least 10 images per animal were visualized under a microscope and digitalized. In each image, two morphometric measurements were performed on the villi and crypts (Fig.2A) randomly chosen with 10x magnification, totaling an " $n$ " of 20 measurements of the same structure per animal, that is, at least 260 measurements (20 measurements per animal x 13 animals) per period.

To count the goblet cells in the intestinal villi(Fig.2C), 5 photomicrographs of each animal were performed, and 10 segments of linear epithelium with $1000 \mu \mathrm{m}$ each were measured, with a $20 \mathrm{x}$ objective.

The villus/crypt ratio was defined by dividing the values of the length of the villi by the depth of the crypt. Histological processing and morphometry were performed according to Moreira Filho et al. (2015).

Data analysis. The measurement of variation of parameters was performed among the different phases of the wintering period of birds in Brazil (south migration, mid-period, north migration) by analysis of variance (ANOVA) with criterion and multiple comparisons and by the Tukey test, with level of significance of $5 \%$. This step was performed on the SPSS 21 program.

\section{RESULTS}

When the thickness of the pectoral muscular fiber was measured, the increase in fiber diameter during wintering was noticeable, with great growth between October and January $(\mathrm{p}<0.05)$ and between January and May $(\mathrm{p}<0.05)$ (Table 1) (Fig.3).

The height of the intestinal villi was greater at arrival to and departure from the island of Restinga; that is, at the beginning and the end of wintering and smaller at mid-period (Table 1). Thus, a relevant change between the arrival and the middle was found $(\mathrm{p}<0.05)$ and between the middle and 
Table 1. Morphometric parameters of the pectoral muscle and the small intestine (SI) of Calidris pusilla during the wintering period on Restinga Island/PB, Brazil

\begin{tabular}{lcrr}
\hline \multirow{2}{*}{ Morphometric parameters } & \multicolumn{2}{c}{ Periods } & Did-period \\
\cline { 2 - 4 } & \multicolumn{1}{c}{ Arrival } & \multicolumn{1}{c}{ Departure } \\
\hline Pectoral muscular fiber thickness $(\mu \mathrm{m})$ & $20.93 \pm 4.61 \mathrm{c}$ & $30.55 \pm 5.51 \mathrm{a}$ \\
Villi/crypt ratio & $6.81 \pm 2.05 \mathrm{a}$ & $4.90 \pm 1.30 \mathrm{c}$ & $5.71 \pm 1.60 \mathrm{~b}$ \\
Intestinal villi height $(\mu \mathrm{m})$ & $462.28 \pm 103.23 \mathrm{a}$ & $443.90 \pm 68.28 \mathrm{~b}$ & $473.29 \pm 80.76 \mathrm{a}$ \\
Intestinal crypts depth $(\mu \mathrm{m})$ & $71.12 \pm 8.37 \mathrm{c}$ & $95.91 \pm 11.33 \mathrm{a}$ & $87.24 \pm 11.85 \mathrm{~b}$ \\
Goblet cells level in SI & $0.028 \pm 0.007 \mathrm{a}$ & $0.030 \pm 0.008 \mathrm{a}$ & $0.031 \pm 0.009 \mathrm{a}$
\end{tabular}

Means followed by different letters on the same line differ by the Tukey test $(\mathrm{P}<0.05)$. Arrival = May, mid-period = October, departure $=$ January.

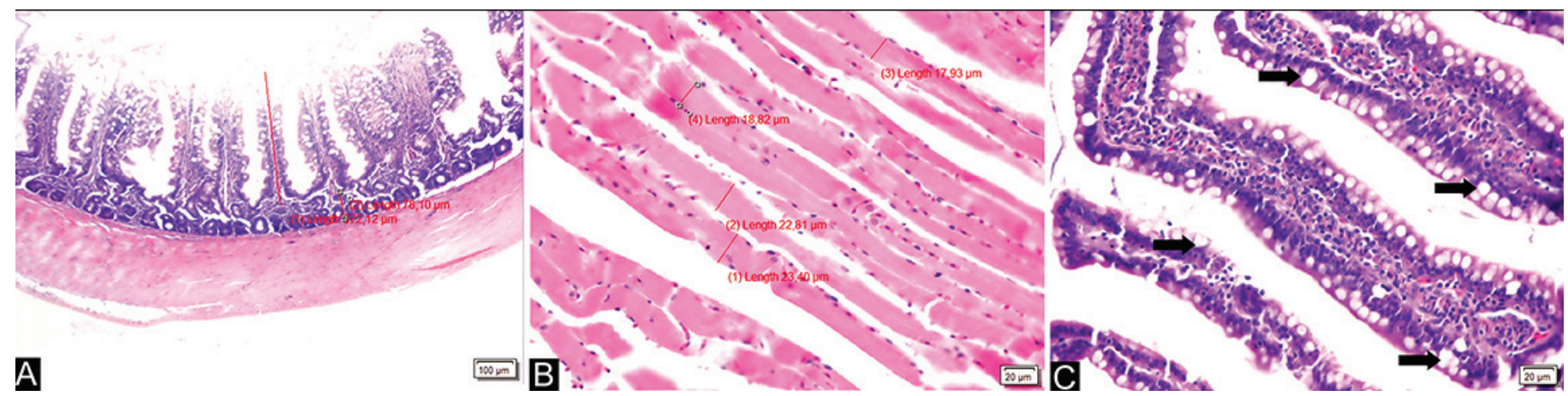

Fig.2. Morphometric analyses of the variables of the intestine and pectoral muscle were performed. (A) Measurement of villus and duodenal crypt (red line and numbers in photomicrography). (B) Measurement of pectoral muscle fiber thickness (red line and numbers in photomicrography). (C) Villi with goblet cells (arrows) which were measured.
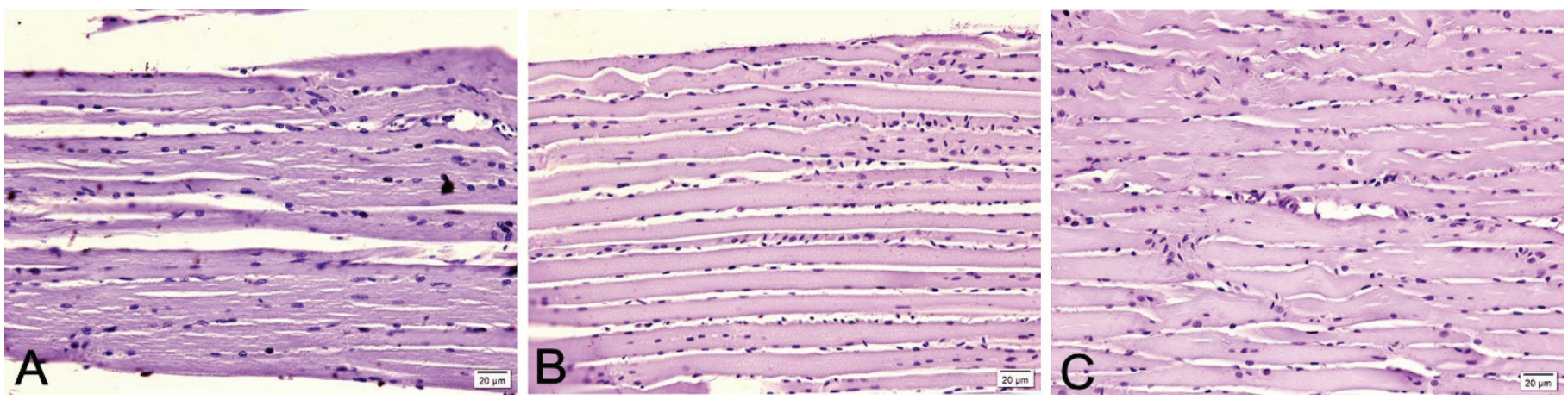

Fig.3. Photomicrographs of the pectoral muscle fibers of Calidris pusilla. (A) Muscular fibers on arrival of birds. Bar=20 $\mu$ m. (B) Muscle

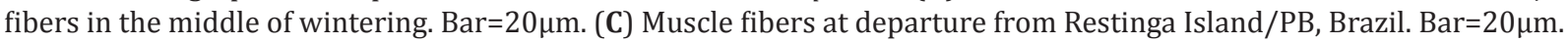

departure $(\mathrm{p}<0.05)$, and no significance was found between arrival and departure (Table 1).

In relation to the depth of the intestinal crypts, there was an increase in depth between the beginning and the middle of wintering $(p<0.05)$, and a decrease at departure $(p<0.05)$. The depth of the crypt at departure was greater than at arrival $(\mathrm{p}<0.05)$ (Table 1).

The variation of the values of the villi/crypt ratio was significant among the three groups compared $(p<0.05)$, showing a decrease between the arrival and mid-winter and then a growth between the middle and departure from the Brazilian coast (Table 1), and this ratio was lower at departure than at arrival.
Likewise, the level of goblet cells in the small intestine did not present significant alteration during wintering on the Brazilian coast (Table 1).

\section{DISCUSSION}

We analyzed the pectoral muscle fibers and intestinal structures, which showed significant variations of some parameters that can clarify biological adaptations of Calidris pusilla during the migratory cycle, and that can be expected in other species of migratory wading birds submitted to the same conditions.

In general terms, the modifications found in the comparison of the structures among the three moments measured during the wintering period (arrival - October, middle - January and 
departure - May), corroborate the proposal of the structural dynamism that occurs in the organs of these animals that perform long flights (Bauchinger \& McWilliams 2010), with increased attention to growth of flight muscles and organ alterations related to nutrition. Although the aforementioned work reports such changes in the organs, this is the first study that demonstrates alterations measured by histomorphometric techniques.

The results of the analysis of the muscle fibers of the pectoral muscle showed that there is a gradual increase of fiber thickness during wintering on the Brazilian coast, in Paraíba. This increase may be related to a large supply of protein through the diet that acts as a stimulus for the growth of this musculature at a cellular and macroscopic level (Piersma 1998).

During the arrival period in Brazil, in October, the pectoral muscle fibers presented a smaller thickness, as initially expected, due to the long flight that birds were submitted to in the displacement from the Northern to the Southern Hemispheres. Therefore, it is evident that this musculature is mobilized and consumed as a source of energy in situations of depletion of lipid reserves, a process already explained by Biebach (1998), leading to a smaller size (atrophy) of the muscle fiber and the muscle bundle as a whole. Hence, we presume that during the migratory flight, the birds aside from using fat reserves, used not only glycogen stocks, but also amino acids from the pectoral muscles, and thus reduced their thickness.

In January, mid-wintering, there was an expressive gain in the thickness of the pectoral muscle fibers, probably due to the great food supply found. At the end of the wintering period, in May, the thickness was even greater, consisting in the preparation for the next long-distance crossing that is the return to the North American continent. This greater thickness of muscle cells characterizes skeletal striated muscle hypertrophy of the pectorals, which may be related to the predisposition for intense activity related to the flight (Meloni 2005).

The hypertrophy found in the pectoral muscles of these birds during wintering in Brazil is fundamental as a strategy for the success of the great displacement performed by these animals, in which part of the nutrients found in the musculature will be used again in the crossing, with feeding occurring only on the few stops until they arrive at their final destination in the north of the American continent. In addition to helping nutritionally subsidize migration, this hypertrophy is important since the pectoral muscles are the most required during long-distance flights.

The expressive muscle growth found was also compatible with data collected in other Calidris sp. species (Dietz et al. 1999), in which the ultrasound technique was used to verify such alterations. Although the aforementioned study and the present study have demonstrated the effect of pectoral muscle hypertrophy during wintering, the physiological mechanism by which this muscle growth occurs is not fully understood.

Rodrigues et al. (2016) recorded that muscle fiber hypertrophy expresses consonance and should contribute to the growth of body mass, and verified the occurrence of a significant increase in body mass in individuals of $C$. pusilla during wintering on the Brazilian coast, with larger masses recorded during the end of this period.
There are studies, mainly in poultry production, that demonstrate the great plasticity of the digestive system in relation to modifications in the diet, such as supplementation of essential amino acids, energy levels, and protein, among others (Starck 1999, Aptekmann et al. 2001, Ramalho de Lima et al. 2013, Moreira Filho et al. 2015, Porto et al. 2015). However, there are incipient studies in wild birds, especially migratory birds. In the poultry production studies, morphological modifications were noticed in intestines, villus height, crypt depth, villus/crypt ratio, and even the amount of goblet cells that produce the mucus that protects the intestinal mucosa from pathogens and assist in the flow of the food bolus through the digestive system (Gomide-Junior et al. 2004, Ramalho de Lima et al. 2013, Moreira Filho et al. 2015).

In relation to migratory birds, Karasov et al. (2004) demonstrated that the organs related to the digestion and assimilation of food in the Sylvia atricapilla Passeriformes species suffer decrease and increase when faced with deprivation or food supply, respectively, during migration. The authors also affirm that the intestine is one of the organs where these changes occur more markedly, which explains the intestinal structural changes presented in this study.

The increase in crypt depth is related to the increase in the cellular proliferation required by the intestinal epithelium through tissue injury or to increase villus height in order to increase the area of absorption through a greater supply of nutrients, since it is in this region where most of the cell proliferation in the intestine is found (Moreira Filho et al. 2015). The increase in villus height increases the area of absorption, that is, it increases the area of intestinal epithelium in contact with the food ingested, thus absorbing more nutrients.

In commercial poultry production, the villus/crypt ratio is taken into account to determine good intestinal health: the higher the ratio, the better; that is, high villus and lower crypt depth, since in this case the increased crypt is normally related to mechanical, microbial or parasitic epithelial injury (Moreira Filho et al. 2015, Porto et al. 2015). However, such an analysis cannot be the same in migratory birds, in which increased crypt depth, or, increased cell division, can and should occur to increase intestinal villi upon the arrival of birds in a feeding area, and this may be a biological adaptation determined by migratory behavior. This increase in crypt depth can be observed in mid-wintering in Brazil in the present study. Nutritionally speaking, increased cell proliferation is an extensive process. Studies indicate that up to $20 \%$ of all energy consumed is spent for the cellular renewal of the intestine, and in birds, this value is even greater (Moreira Filho et al. 2015). Therefore, only under conditions of great supply of nutrients, as possibly found during the wintering period in Brazil, such process can be carried out. Nutritional demand, coupled with the physiology of migration, may explain why the intestinal crypts have their lowest depth upon arrival in Brazil, after the south migration in which there are few stops along the migratory route, that is, with low availability of nutrients.

The fact that intestinal villus height is higher during the arrival and departure phases in the wintering period should be related to the nutritional efficiency that allows mass/fuel accumulation for migration. C. pusilla arrives in South America through direct flights of only six days after the refueling period in James Bay, Canada, for example (Brown \& 
Jordan 2014), therefore the intestinal villi may still present height with regard to this period of supply, when the birds arrive in Brazil. In the case of the departure phase, the villi are modified at the time of supply on the Brazilian coast, in preparation for the flight back to the Northern Hemisphere. During the wintering period, the height of the villi is lower, even if the birds are in the same environments as in the arrival and departure periods. Thus, changes in villi appear to be related to the physiological changes of the birds and not to the availability of food resources in the environment.

The number of goblet cells in the intestinal mucosa, expressed in number of cells per micrometer, did not change in the studied stages of wintering, even when there were histological modifications resulting from greater availability of nutrients, differently from those observed in poultry production (Gomide-Junior et al. 2004, Ramalho de Lima et al. 2013, Moreira Filho et al. 2015).

\section{CONCLUSIONS}

During the wintering period on the coast of Brazil, the migratory wading bird Calidris pusilla presents morphological alterations such as the increase of the thickness of the pectoral muscular fiber and the increase of the intestinal crypts where the cellular proliferation occurs that allows the growth of the intestinal villi and subsequent increase of nutrient absorption. Such changes occur temporarily to the activities of preparation and the migratory flight between the northern and southern hemispheres.

More studies on the morphometric characteristics of the intestine and muscle of these birds, especially at breeding sites in North America, are required for comparisons and morphological and physiological details of the migration to be clarified.

\section{REFERENCES}

Alerstam T., Hedenström A. \& Åkesson S. 2003. Long distance migration: evolution and determinants. Oikos. Synthesising Ecol. 103:247-260.

Andres B.A., Smith P.A., Morrison R.I.G., Gratto-Trevor C.L., Brown S.C. \& Friis C.A. 2012. Population estimates of North American shorebirds. Wader Study Group Bulletin 119(3):178-194.

Aptekmann K.P., Baraldi Arton S.M., Stefanini M.A. \& Orsi M.A. 2001. Morphometric analysis of the intestine of domestic quails (Coturnix coturnix japonica) treated with different levels of dietary calcium. Anat. Hist. Embryol. 30(5):277-280. <http://dx.doi.org/10.1046/j.1439-0264.2001.00331.x> $<$ PMid:11688737>

Azevedo-Júnior S.M., Dias M.M., Larrazábal M.E. \& Fernandes C.J.G. 2002. Capacidade de vôo de quatro espécies de Charadriiformes (Aves) capturadas em Pernambuco, Brasil. Revta Bras. Zool. 19(1):183-189. < https://doi. org/10.1590/S0101-81752002000500013>

Battley P.F., Piersma T., Dietz M.W., Tang S., Dekinga A. \& Hulsman, K. 2000. Empirical evidence for differential organ reductions during trans-oceanic bird flight. Proc. R. Soc. London, Biol. Sci. 267(1439):191-195. <http:// dx.doi.org/10.1098/rspb.2000.0986>.

Bauchinger U. \& McWilliams S.R. 2010. Extent of phenotypic flexibility during long-distance flight is determined by tissue-specific turnover rates: a new hypothesis. J. Avian Biol. 41(6):1-7. <http://dx.doi.org/10.1111/j.1600048X.2010.05137.X>

Biebach H. 1998. Phenottypic organ flexibility in garden warblers Sylvia borin during long-distance migration. J. Avian Biol. 29(4):529-535. <http:// dx.doi.org/10.2307/3677172>
Biewener A.A. 2011. Muscle function in avian flight: achieving power and control. Phil. Trans. R. Soc. B 366(1570):1496-1506. <http://dx.doi. org/10.1098/rstb.2010.0353><PMid:21502121>

Blem C.R. 1980. The energetics of migration, p.174-224. In: Gauthreaux S.A. (Ed), Animal Migration, Orientation and Navigation. Academic Press, Orlando. <http://dx.doi.org/10.1016/B978-0-08-091833-4.50008-0>.

Brown S. \& Jordan H. 2014. First ever geolocator results semipalmated sandpiper show remarkable year long odyssey. Available at <https://www. manomet.org/newsletter/ first-ever-geolocator-results-semipalmatedsandpiper-show-remarkable-year-long-odyssey> Access on July 30, 2014.

Cadrin S.X. 2000. Advances in morphomteric identification of fishery stock. Revs Fish Biol. Fisheries 10(1):91-112. <http://dx.doi.org/10.1023/A:1008939104413>

Cavalcanti M.J. \& Lopes P.R.D. 1990. Morfometria comparada de Ctenosciaena gracilicirhus, Paralonchurus brasiliensis e Micropogonias furnieri (Teleostei: Sciaenidae) pela análise multivariada de redes de treliças. Revta Bras. Zool. 7(4):627-635. <http://dx.doi.org/10.1590/S0101-81751990000400016>

Connell C.E., Odum E.P. \& Kale H. 1960. Fat-free weights of birds. The Auk, Q. J. Ornithol. 77:1-9.

Dietz M.W., Piersma T. \& Dekinga A. 1999. Body-building without power training: endogenously regulated Pectoral muscle hypertrophy in confined shorebirds. J. Exp. Biol. 202(Pt 20):2831-2837. <PMid:10504319>

Gomide-Junior M.L., Sterzo E.V., Macari M. \& Boleli I.C. 2004. Use of scanning eléctron microscopy for the evaluation of intestinal epithelium integrity. Revta Bras. Zootec. 33(6):1500-1505. <http://dx.doi.org/10.1590/S151635982004000600017>

Jehl J.R. 1997. Cyclical changes in body composition in the annual cycle and migration of the Eared Grebe Podiceps nigricollis. J. Avian Biol. 28(2):132142. <http://dx.doi.org/10.2307/3677306>

Junqueira L.C. \& Carneiro J. 2008. Histologia Básica. Editora Guanabara Koogan, Rio de Janeiro, p.3-4.

Karasov W.H. \& Pinshow B. 1998. Changes in lean mass and in organs of nutrient assimilation in a long-distance passerine migrant at a springtime stopover site. Physiol. Zool. 71(4):435-448. <http://dx.doi.org/10.1086/515428> <PMid:9678504>

Karasov W.H., Pinshow B., Starck J.M. \& Afik D. 2004. Anatomical and histological changes in the alimentary tract of migrating (Sylvia atricapilla): a comparison among fed, food-restricted, and refed birds. Physiol. Biochem. Zool. 77(1):149-160. <http://dx.doi.org/10.1086/381465><PMid:15057725>

Landini G.F., Di Vito Neto A., Schwantes A.R., Schwantes M.L.B. \& Santos M. 2013. Intraerythrocytic organic phosphates and hemoglobins of skua Catharacta maccormicki (Stercoraridae): at two different stages of the year in relation to Antartic migration. Braz. Arch. Biol. Technol. 56(4):599-606. <http://dx.doi.org/10.1590/S1516-89132013000400010>

Larrazábal M.E., Azevedo Júnior S.M. \& Pena O. 2002. Monitoramento de aves limícolas na Salina Diamante Branco, Galinhos, Rio Grande do Norte, Brasil. Revta Bras. Zool. 19(4):1081-1089. <http://dx.doi.org/10.1590/ S0101-81752002000400013>

Lindstrom A. \& Piersma T. 1993. Mass changes in migrating birds: the evidence for protein storage re-examined. Ibis. Int. J. Avian Sci. 135:70-78.

Meloni V.H.M. 2005. O papel da hiperplasia na hipertrofia do músculo esquelético. Revta Bras. Cineantropomet. Desemp. Humano 1:59-63.

Moraes D.A. 2003. A Morfometria Geométrica e a sua "Revolução na Morfometria": localizando e visualizando mudanças na forma dos organismos. Bioletim 3:1-5.

Moreira Filho A.L.B., Oliveira C.J.B., Oliveira H.B., Campos D.B., Guerra R.R., Costa F.G.P. \& Givisiez P.E.N. 2015. High incubation temperature and threonine dietary level improve ileum response against post-hatch Salmonella enteritidis inoculation in broiler chicks. Plos One 10(7):e0131474. <http:// dx.doi.org/10.1371/journal.pone.0131474 ><PMid:26131553> 
Morrison R.G. 1984. Migration systems of some new world shorebirds, p.125202. In: Burger J. \& Olla B.L. (Eds), Behavior of Marine Animals, Shorebirds: migration and forangins behavior. Vol. 6. Plenum Press, New York. 743p.

Odum E.P., Rogers D.T. \& Hicks D.L. 1964. Homeostasis of the nonfat components of migrating birds. Science 143(3610):1037-1039. <http:// dx.doi.org/10.1126/science.143.3610.1037> <PMid:14107427>

Oliveira A.C., Barbosa A.E.A., Sousa A.E.B.A., Lugarini C., Lima D.M., Nascimento J.L.X., Souza M.A., Somenzari M., Souza N.A., Serafini P.P., Amaral P.P., Rossato R.M. \& Medeiros R.C.S. 2016. Relatório anual de rotas e áreas de concentração de aves migratórias no Brasil. Centro Nacional de Pesquisa e Conservação de Aves Silvestres (Cemave), Instituto Chico Mendes de Conservação da Biodiversidade (ICMBio), Cabedelo, PB. 63p.

Phillips A.R. 1975. Semipalmated Sandpiper: identification, migrations, summer and winter ranges. Am. Birds 29:799-806.

Piersma T. 1998. Phenotypic flexibility during migration: optimization of organ size contingent on the risks and rewards of fueling and flight? J. Avian Biol. 29(4):511-520. <http://dx.doi.org/10.2307/3677170>

Pires D.L. 2008. Efeito da inoculação via esofágica de microbiota intestinal sobre a hematologia, desenvolvimento e integridade intestinal de pintos de corte. Dissertação de Mestrado, Faculdade de Ciências Agrárias e Veterinárias, Universidade Estadual Paulista, Jaboticabal. 96p.
Porto M.L., Gviziez P.E.N., Saraiva E.P., Costa F.G.P., Moreira Filho A., Andrade M.F.S., Brandao P.A. \& Guerra R.R. 2015. Glutamic acid improves body weighy gain and intestinal morphology of broiler chickens submitted to heat stress. Revta Bras. Ciênc. Avícola 17:355-362.

Ramalho de Lima M., Costa F.G.P., Guerra R.R., Da Silva J.H., Rabello C.B.V., Miglino M.A., Lobato G.B.V., Sena Netto S.B. \& Dantas L.D.S. 2013. Threonine: lysine ratio for Japanese quail hen diets. J. Applied Poult. Res. 22(2):260268. <http://dx.doi.org/10.3382/japr.2012-00670>

Rodrigues R.C., Azevedo Júnior S.M., Larrazabal M.E.L. \& Araújo H.F.P. 2009. Temporal variations of body mass and plumage in Arenaria interpres (Aves, Scolopacidae) along the Brazilian coast. Zoologia 26(3):386-390. <http:// dx.doi.org/10.1590/S1984-46702009000300002>

Rodrigues R.C., Araújo H.F.P., Guerra R.R., Durigon E.L, Mizrahi D.S. \& Azevedo Junior S.M. 2016. Temporal variation in the mas and plumage of four Charadriiformes species on the north-eastern coast of Brazil. Emu, Austral Ornithol., Melbourne, 116(4):1-6.

Sick H. 1997. Ornitologia Brasileira. Nova Fronteira, Rio de Janeiro. 912p.

Starck J.M. 1999. Structural flexibility of the gastro-intestinal tract of vertebrates. Implications for evolutionary morphology. Zool. Anz. 238:87-101. 